\title{
Effects of Phosphate Limitation of Growth on the Cell-wall and Lipid Composition of Saccharomyces cerevisiae
}

\author{
By ANDREW M. RAMSAY* AND L. JULIA DOUGLAS \\ Department of Microbiology, University of Glasgow, \\ Garscube Estate, Bearsden, Glasgow G61 1QH
}

(Received 31 July 1978)

The phosphorus content of phosphate-limited Saccharomyces cerevisiae was only $71 \%$ of that of non-limited yeast. Walls prepared from phosphate-limited cells contained slightly less phosphorus than control walls. No evidence was obtained for the presence in these walls of uronic acid or succinyl residues. The carbohydrate content of walls of phosphatelimited yeast was less than that of non-limited walls, and this was reflected in a decreased glucan content. There was only a slight decrease in glucosamine content while the protein content increased. The major change in the lipid composition of phosphate-limited yeast was a decrease in both sterol esters and triacylglycerols. There was a decrease in total lipid content, but increased production of phosphatidylethanolamine and phosphatidylcholine. The phosphatidylserine content was decreased. These results suggest that there are fewer intracellular low-density vesicles in phosphate-limited yeast.

\section{INTRODUCTION}

Phosphate limitation of growth induces substantial changes both in the cell-wall composition and in the lipid composition of certain bacteria. These include replacement of wall teichoic acid by a phosphorus-free anionic polymer, teichuronic acid (Ellwood \& Tempest, 1972), and partial replacement of acidic phospholipids by acidic glycolipids (Minnikin et al., 1974). By contrast, very little is known of the effects of this growth constraint on the composition of the yeast Saccharomyces cerevisiae. The present paper reports an analysis of the changes in cell-wall and lipid composition resulting from growth of $S$. cerevisiae NCYC 366 under phosphate limitation. This strain was chosen because its lipid composition, under a variety of other growth conditions, has been well documented (Hunter \& Rose, 1972).

\section{METHODS}

Organism and growth media. Saccharomyces cerevisiae NCYC 366 was grown in the defined medium of Rose $\&$ Nickerson (1956) supplemented with L-asparagine $\left(1 \mathrm{~g} \mathrm{l}^{-1}\right)$. For phosphate-limited cultures, the concentration of $\mathrm{KH}_{2} \mathrm{PO}_{4}$ was decreased from $3 \mathrm{~g}^{-1}$ to $81.6 \mathrm{mg} \mathrm{l}^{-1}$. Stock cultures were maintained at $4^{\circ} \mathrm{C}$ on slopes of complete medium.

Experimental cultures. Non-phosphate-limited (control) cells were grown in batches at $30{ }^{\circ} \mathrm{C}$ in a 151 fermenter (LH Engineering Co., Stoke Poges, Bucks.). An overnight culture ( $0.5 \mathrm{l})$ was used to inoculate 14.5 1 medium. Mixing was accomplished by an impeller operating at $400 \mathrm{rev}$. $\mathrm{min}^{-1}$ and sterile air was sparged through the culture at $101 \mathrm{~min}^{-1}$. Cells were harvested in the mid-exponential phase of growth $\left(A_{650}^{1 \mathrm{~cm}} 1 \cdot 0\right)$ when the growth rate was $0 \cdot 34 \mathrm{~h}^{-1}$.

Phosphate-limited cells were grown continuously at $30^{\circ} \mathrm{C}$ in a 21 chemostat (Hunter \& Rose, 1972). The dilution rate was $0.23 \mathrm{~h}^{-1}$. At regular intervals samples were removed aseptically through a drain point in

* Present address: Strathclyde Regional Council, Department of the Regional Chemist, Public Analyst and Agricultural Analyst, Clydeway Industrial Centre, 8 Elliot Place, Glasgow. 
the floor of the vessel and used to check the purity, absorbance $\left(A_{650}^{\mathrm{1cm}}\right)$ and $\mathrm{pH}$ of the culture. The concentration of orthophosphate (as phosphorus) in cell-free filtrates was also monitored. Steady-state cells were harvested either by draining the vessel to about $10 \%$ (v/v) of the initial volume or by recovery from the chilled overflow receiver at short, regular intervals. Cells from both batch and continuous cultures were washed twice in $0.85 \%(\mathrm{w} / \mathrm{v}) \mathrm{NaCl}$ and once in distilled water at $4{ }^{\circ} \mathrm{C}$. They were then either stored at $-20{ }^{\circ} \mathrm{C}$ or freeze-dried and stored in vacuo over silica gel.

Preparation of walls. Cells were suspended in cold water (approximately $10 \mathrm{~g}$ wet wt cells in $10 \mathrm{ml}$ water) and shaken with no. 10 Ballotini beads $(10 \mathrm{~g})$ for 75 to $90 \mathrm{~s}$ at $4000 \mathrm{rev} . \mathrm{min}^{-1}$ in a Braun MSK homogenizer (B. Braun, Melsungen, West Germany). The temperature was maintained at 0 to $4{ }^{\circ} \mathrm{C}$ throughout the disruption. Beads were removed by filtration through a sintered glass filter (porosity grade 0 ) and the filtrate was centrifuged at $750 \mathrm{~g}$ for $20 \mathrm{~min}$. The wall pellet was washed 10 times in $0 \cdot 1 \mathrm{M}$-Tris/ $\mathrm{HCl}$ buffer $(\mathrm{pH} \mathrm{7 \cdot 2)}$ and then four times in distilled water; the temperature remained below $4{ }^{\circ} \mathrm{C}$ throughout. Absence of intact yeast from the wall preparations was established by phase-contrast microscopy. Walls were freeze-dried and stored in vacuo over silica gel.

Treatment of walls with $\beta$-glucanase and $\alpha$-mannosidase. A suspension of walls $(12 \mathrm{mg})$ in $6 \mathrm{ml} 0.05 \mathrm{M}$ sodium citrate buffer ( $\mathrm{pH} 5 \cdot 0$ ), containing $10 \mathrm{mM}-\mathrm{MgCl}_{2}$ and $10 \mathrm{mM}-\mathrm{ZnSO}_{4}$, was supplemented with 3.75 units of $\alpha$-mannosidase and 50 units of $\beta$-glucanase solution $\left(10 \mathrm{mg} \mathrm{ml}^{-1}\right)$ and incubated at $30^{\circ} \mathrm{C}$ for $35 \mathrm{~min}$. Portions $(0 \cdot 1 \mathrm{ml})$ removed at time zero and after $35 \mathrm{~min}$ were diluted to $3 \mathrm{ml}$ with distilled water and their absorbance at $650 \mathrm{~nm}$ was measured against a distilled water blank.

Acid hydrolysis of enzymically treated wall suspensions. Portions of wall suspension, equivalent to $3.6 \mathrm{mg}$ untreated wall, were hydrolysed in $1 \mathrm{M}-\mathrm{HCl}$ at $105{ }^{\circ} \mathrm{C}$ in vacuo for 2 to $4 \mathrm{~h}$. Following neutralization with $0.5 \mathrm{M}-\mathrm{KOH}$, the hydrolysates were centrifuged at $1100 \mathrm{~g}$ for $5 \mathrm{~min}$ to remove insoluble material and stored at $-20^{\circ} \mathrm{C}$.

Analysis of walls and wall hydrolysates. Prior to analysis all wall suspensions were homogenized for $1 \mathrm{~min}$ in a sonic water bath. Total carbohydrate was determined by the phenol-sulphuric acid method (Dubois et al., 1956). Glucose and mannose were determined enzymically, glucose by the glucose oxidase reagent and mannose by the method of Gawehn (1974). Phosphorus was estimated as described by Letters (1964). Protein (as bovine serum albumin) was determined by the method of Lowry et al. (1951); prior to analysis wall samples were digested in dilute alkali $\left[2 \%(\mathrm{w} / \mathrm{v}) \mathrm{Na}_{2} \mathrm{CO}_{3}\right.$ in $\left.0 \cdot 1 \mathrm{M}-\mathrm{NaOH}\right]$ in glass-stoppered tubes for $30 \mathrm{~min}$ in a steam bath. Glucosamine was assayed by the method of Rondle \& Morgan (1955) following hydrolysis of walls in $2 \mathrm{M}-\mathrm{HCl}$ at $105^{\circ} \mathrm{C}$ in vacuo for $4 \mathrm{~h}$.

Paper chromatography. Descending chromatography was carried out on Whatman no. 1 paper in the following solvent systems: A, butan-1-ol/pyridine/water (6:4:3, by vol.); B, ethyl acetate/pyridine/acetic acid/water (5:5:1:3, by vol.). Hydrolysis products were identified by co-chromatography with authentic standards and the use of the following specific spray and dip reagents: alkaline silver nitrate for sugars (Trevelyan et al., 1950); aniline-diphenylamine for neutral sugars and uronic acids (Bailey, 1969); bromophenol blue for non-volatile acids (Kennedy \& Barker, 1951); bromocresol green-bromophenol bluepermanganate for non-volatile acids (Pásková \& Munk, 1960).

Lipid analyses. Lipids were extracted from cells, and determinations were made of total lipid, total phospholipid, individual phospholipids and acylglycerols as described by Hunter \& Rose (1972) and Hossack \& Rose (1976). Free sterols were assayed by a modification of the method of Jatzkewitz \& Mehl (1960). Samples of sterol solution, containing up to $0 \cdot 1 \mathrm{mg}$ sterol, were evaporated to dryness using a stream of nitrogen. Then $2 \mathrm{ml}$ sulphuric acid (sp.gr. 1.84)/glacial acetic acid $(1: 1, \mathrm{v} / \mathrm{v})$ were added to each tube, and the tubes were placed in a water bath at $90^{\circ} \mathrm{C}$ for $15 \mathrm{~min}$. After cooling, the absorbance at $390 \mathrm{~nm}$ was measured against a reagent blank; ergosterol was used as a standard. Sterol esters were assayed by determining the amount of free sterol liberated upon saponification (Hunter \& Rose, 1972).

Chemicals. Basidiomycete QM806 $\beta$-glucanase was kindly provided by Professor A. H. Rose (University of Bath). $\alpha$-Mannosidase and the glucose oxidase blood sugar kit were obtained from Boehringer; silica gel was from Merck. All other biochemicals were purchased from Sigma. Solvents and other chemicals were of analytical grade where available and were obtained from BDH. All solvents were distilled prior to use and were stored over a drying agent.

Statistical analyses. Results were expressed as the sample mean \pm the standard error of the mean. The significance of differences in sample means was determined by the $t$-test and the level of probability $(P)$ at which the null hypothesis be rejected was noted. The reliability of the $t$-test depends on the standard deviations of the means being similar. The variance ratio test was employed to check the equality of these standard deviations. If, by the variance ratio test, the standard deviations were unacceptably dissimilar, then the result of the $t$-test was discarded. 
Table 1. Effect of phosphate limitation on the cell-wall composition of

S. cerevisiae

\begin{tabular}{|c|c|c|}
\hline \multirow[b]{2}{*}{ Component } & \multicolumn{2}{|c|}{$\begin{array}{l}\text { Percentage composition }(\mathrm{w} / \mathrm{w}) \text { of } \\
\text { wall preparation* }\end{array}$} \\
\hline & Control & Phosphate-limited \\
\hline Carbohydrate & $83.55 \pm 1.28(9)$ & $72 \cdot 20 \pm 1 \cdot 06(9)$ \\
\hline Protein & $14.80 \pm 0.37(9)$ & $18.28 \pm 0.43(9)$ \\
\hline Phosphorus & $0.75 \pm 0.01$ & $0.70 \pm 0.01(9)$ \\
\hline Glucosamine & $1.91 \pm 0.14(2)$ & $1.73 \pm 0.02$ \\
\hline
\end{tabular}

* Values quoted are means \pm the standard error of the mean, with the number of replicate determinations shown in parentheses.

\section{RESULTS}

Total phosphorus content of whole cells

The phosphorus content of phosphate-limited cells $\left[2 \cdot 34 \pm 0.14 \mathrm{mg}(100 \mathrm{mg} \text { dry wt })^{-1}\right.$; nine determinations] was only $71 \%$ of that of control cells [3.29 \pm 0.08 ; nine determinations].

\section{Effect of phosphate limitation on wall composition}

Qualitative analysis. Paper chromatography of hydrolysed wall preparations $(2 \mathrm{M}-\mathrm{HCl}$ at $105^{\circ} \mathrm{C}$ for $3 \mathrm{~h}$ in vacuo) revealed the presence of glucose, mannose and glucosamine in hydrolysates of both control and phosphate-limited yeast walls. Treatment of the wall preparations with $\beta$-glucanase and $\alpha$-mannosidase, followed by acid hydrolysis under rather milder conditions, gave $N$-acetylglucosamine as an additional product. No evidence was obtained for the presence of uronic acids in any of the hydrolysates. Similarly, succinic acid, which is a substituent of the acidic lipomannan of Micrococcus lysodeikticus (Owen \& Salton, 1975), was not found. However, the spray reagent (Pásková \& Munk, 1960) used for the detection of succinic acid did reveal two unidentified, but presumably acidic, components ( $R_{\text {glucose }} 0.60$ and 0.86 ; solvent $\mathrm{A}$ ) which appeared to be present in greater amounts in hydrolysates of walls from phosphate-limited yeast.

Quantitative analysis. The carbohydrate, protein, phosphorus and glucosamine contents of wall preparations are shown in Table 1. Walls from phosphate-limited yeast contained significantly less total carbohydrate $(P=0.001)$ but more protein than control walls. The phosphorus content of phosphate-limited yeast walls was only slightly, but nevertheless significantly $(P=0.05)$, lower, while the glucosamine content was also marginally lower.

To determine the relative amounts of glucan and mannan present, wall suspensions were treated with $\beta$-glucanase and $\alpha$-mannosidase prior to hydrolysis in $1 \mathrm{M}-\mathrm{HCl}$. The enzymic treatment solubilized a considerable proportion of both wall preparations such that the absorbance $\left(A_{650}^{1 \mathrm{~cm}}\right)$ of the control and phosphate-limited yeast wall suspensions fell by $47.2 \%$ and $23 \cdot 3 \%$, respectively. All of the wall carbohydrate was released during the subsequent acid hydrolysis (Table 2), that from phosphate-limited yeast walls being released more rapidly. The recovery of carbohydrate as glucose plus mannose was between $74 \%$ (phosphate-limited) and $81 \%$ (control) of the total carbohydrate released from the wall. The mannose contents of the two wall preparations were similar ( 23 to $24 \%$ ) but phosphatelimited yeast walls contained much less glucose $(28 \%)$ than did control walls $(45 \%)$.

\section{Effect of phosphate limitation on lipid content and composition}

Phosphate-limited yeast contained less total lipid [13.30 $\pm 0.39 \mathrm{mg}(100 \mathrm{mg} \text { dry wt })^{-1}$; three determinations] than control cells [14.73 \pm 1.03 ; four determinations]. However, the phospholipid content of phosphate-limited cells $\left[4 \cdot 79 \pm 0 \cdot 10 \mathrm{mg}\left(100 \mathrm{mg}\right.\right.$ dry wt) ${ }^{-1} ; 12 \mathrm{de}-$ terminations] was higher than that of control cells [3.90 $\pm 0 \cdot 21$; three determinations]. A complex series of changes in lipid composition were observed, those in neutral lipids 
Table 2. Release of total carbohydrate, glucose and mannose from cell walls of $S$. cerevisiae during acid hydrolysis

\begin{tabular}{|c|c|c|c|c|c|}
\hline \multirow[b]{2}{*}{$\begin{array}{c}\text { Wall } \\
\text { preparation }\end{array}$} & \multirow{2}{*}{$\begin{array}{l}\text { Duration of } \\
\text { hydrolysis } \\
\text { (h) }\end{array}$} & \multirow{2}{*}{$\begin{array}{l}\text { Percentage } \\
\text { (w/w) of wall } \\
\text { carbohydrate } \\
\text { released }\end{array}$} & \multicolumn{3}{|c|}{ Percentage $(w / w)$ of wall released as: } \\
\hline & & & $\begin{array}{c}\text { Total } \\
\text { carbohydrate }\end{array}$ & Mannose & Glucose \\
\hline Control & $\begin{array}{l}2 \\
3 \\
4\end{array}$ & $\begin{array}{r}81 \cdot 1 \\
95 \cdot 2 \\
102 \cdot 5\end{array}$ & $\begin{array}{l}67 \cdot 8 \\
79 \cdot 5 \\
85 \cdot 6\end{array}$ & $\begin{array}{l}18 \cdot 3 \\
20 \cdot 7 \\
24 \cdot 2\end{array}$ & $\begin{array}{l}38 \cdot 6 \\
42 \cdot 4 \\
45 \cdot 2\end{array}$ \\
\hline Phosphate-limited & $\begin{array}{l}2 \\
3 \\
4\end{array}$ & $\begin{array}{l}99 \cdot 1 \\
96 \cdot 8 \\
99 \cdot 1\end{array}$ & $\begin{array}{l}71 \cdot 5 \\
69 \cdot 9 \\
71 \cdot 5\end{array}$ & $\begin{array}{l}17 \cdot 6 \\
23 \cdot 8 \\
20 \cdot 0\end{array}$ & $\begin{array}{l}27 \cdot 0 \\
27 \cdot 9 \\
26 \cdot 1\end{array}$ \\
\hline
\end{tabular}

Table 3. Effect of phosphate limitation on the neutral lipid composition of S. cerevisiae

\begin{tabular}{|c|c|c|}
\hline \multirow[b]{2}{*}{ Component } & \multicolumn{2}{|c|}{ Content $\left[\mathrm{mg}(100 \mathrm{mg} \text { dry wt yeast })^{-1}\right]^{*}$} \\
\hline & Control & Phosphate-limited \\
\hline Triacylglycerol & $0.96 \pm 0.06(4)$ & $0.58 \pm 0.02(4)$ \\
\hline Diacylglycerol & $0.34 \pm 0.07(4)$ & $0.20 \pm 0.02(6)$ \\
\hline Monoacylglycerol & $0 \cdot 17 \pm 0.04$ & Not detected \\
\hline Free fatty acids & $0.07 \pm 0.02(6)$ & $0.82 \pm 0.08(8)$ \\
\hline Sterol & $0.70 \pm 0.09(4)$ & $0.57 \pm 0.06(6)$ \\
\hline Sterol ester & $3 \cdot 90 \pm 0 \cdot 13(4)$ & $1 \cdot 28 \pm 0 \cdot 15(6)$ \\
\hline
\end{tabular}

* Values quoted are means \pm the standard error of the mean, with the number of replicate determinations shown in parentheses.

Table 4. Effect of phosphate limitation on the phospholipid composition of S. cerevisiae

\begin{tabular}{lcc}
\multicolumn{1}{c}{ Component } & Control & Phosphate-limited \\
Phosphatidylcholine & $1.30 \pm 0.04(3)$ & $1.90 \pm 0.05(12)$ \\
Phosphatidylethanolamine & $0.98 \pm 0.12(3)$ & $1.35 \pm 0.03(12)$ \\
Phosphatidylinositol & $0.97 \pm 0.07(3)$ & $1.04 \pm 0.02(12)$ \\
Phosphatidylserine & $0.28 \pm 0.06(3)$ & $0.15 \pm 0.01(12)$ \\
Phosphatidic acid & $0.19 \pm 0.02(3)$ & $0.20 \pm 0.03(12)$ \\
$N, N$-Dimethylphosphatidyl- & $0.03 \pm 0.02(3)$ & Not detected \\
ethanolamine & & \\
Base spot & $0.07 \pm 0.03(3)$ & $0.10 \pm 0.01(12)$
\end{tabular}

Cardiolipin and lysophosphatidylcholine were detected in trace amounts only in extracts of control cells.

* Values quoted are means \pm the standard error of the mean, with the number of replicate determinations shown in parentheses.

being particularly striking (Table 3 ). Phosphate-limited cells contained much less sterol ester and triacylglycerol than control cells $(P=0 \cdot 001)$. The contents of diacylglycerol and free sterol were also lower in the phosphate-limited yeast. Monoacylglycerols were detected only in extracts of control cells. The free fatty acid content of phosphate-limited yeast was 12 to 13 times higher than that of control cells. The difference appeared to be significant $(P=0.001)$ but the validity of the $t$-test was rejected in this instance by the variance ratio test. Phosphate-limited yeast contained more phosphatidylcholine and phosphatidylethanolamine $(P=0.01)$ but less phosphatidylserine $(P=0.001)$ than control cells (Table 4). The phosphatidylinositol and phosphatidic acid contents were similar in both types of cells. Very low concentrations of $N, N$-dimethylphosphatidylethanolamine, lysophosphatidylcholine and cardiolipin were detected only in extracts of control cells. 


\section{DISCUSSION}

The most striking change that phosphate limitation of growth induces in the cell-wall composition of many Gram-positive bacteria is the replacement of teichoic acid by phosphorus-free teichuronic acid. However, no such drastic change in cell-wall composition occurs when $S$. cerevisiae is grown under conditions of phosphate limitation. The phosphate content of the wall in $S$. cerevisiae is attributed to the presence of phosphodiester linkages in the outer chains of wall mannan. This phosphomannan component is presumed to be largely responsible for the negative charge or zeta potential of the cell and thus may be considered formally analogous to teichoic acid in bacteria. It would appear that $S$. cerevisiae is unable to incorporate uronic acids into polymers, even under conditions of phosphate limitation. Although uronic acids are known to be constituents of capsular polysaccharides in some yeasts (Phaff, 1971), their presence in cellular components of $S$. cerevisiae has not been reported. Furthermore, attempts to demonstrate the presence of UDPglucose dehydrogenase in phosphate-limited S. cerevisiae have been unsuccessful (L. J. Douglas, unpublished observations). Under phosphate limitation, cell-wall phosphate may, however, be partially replaced by an increased proportion of other negatively charged constituents. This conclusion is supported by the work of San Blas \& Cunningham (1974) who studied the effect of phosphate deprivation on the composition of mannans produced by Hansenula holstii. When this yeast was grown in a complex culture medium from which $\mathrm{KH}_{2} \mathrm{PO}_{4}$ had been omitted, the wall mannan contained only trace quantities of phosphorus but nevertheless bound in appreciable amounts to a column of DEAE-cellulose. The acidic constituent was not identified.

The major changes in wall composition of phosphate-limited $S$. cerevisiae as compared with control cells were a decreased content of glucan and an increased protein content. Such changes must be examined carefully in the light of the finding by McMurrough \& Rose (1967) that the overall wall composition of $S$. cerevisiae is affected by changes in the growth rate. These workers showed that the protein and phosphorus contents of the wall increased as the growth rate was lowered. The total carbohydrate content, on the other hand, was largely unaffected, as were the relative proportions of glucan and mannan. Thus, the observed decrease in carbohydrate content from $83.5 \%$ (walls of control cells) to $72 \%$ (walls of phosphate-limited cells) can be attributed to a specific effect of phosphate limitation of growth. The increased protein content of walls from phosphate-limited cells, however, may be partially accounted for by the lower growth rate of this culture. Similarly, the relatively high phosphorus content of phosphate-limited yeast walls may reflect a balance between the opposing effects of phosphate limitation, which would tend to decrease the phosphorus content, and a low growth rate, which would tend to increase it.

Hunter \& Rose (1972) compared the lipid composition of S. cerevisiae NCYC 366 grown in a chemostat at rates of $0.25 \mathrm{~h}^{-1}$ and $0.05 \mathrm{~h}^{-1}$. They found that phospholipid synthesis was decreased at the lower growth rate and that this was reflected in lowered levels of phosphatidylethanolamine and, to a much lesser extent, phosphatidylinositol. The phosphatidylserine content was unaffected while the phosphatidylcholine content increased by some $37 \%$. Thus the only change in phospholipid composition of phosphate-limited $S$. cerevisiae which may be attributed to the lower growth rate of this culture is the increased content of phosphatidylcholine. While $S$. cerevisiae may be relatively amenable to changes in phospholipid composition, it would appear to be intolerant of any appreciable diminution in overall phospholipid content. This conclusion is supported by the preliminary report of Johnson et al. (1973) which states that only small differences in polar lipid content and composition were detected when S. cerevisiae NCYC 712 was grown under phosphate limitation. By contrast, when Pseudomonas diminuta is subjected to the same growth constraint, the phospholipid content of the organism falls almost to zero (Minnikin et al., 1974). 
The most noteworthy change in the lipid composition of phosphate-limited cells was their decreased content of sterol esters and triacylglycerols. Moreover this was unlikely to be a growth-rate effect since Hunter \& Rose (1972) demonstrated that lowering the growth rate of $S$. cerevisiae in a chemostat at $30^{\circ} \mathrm{C}$ caused an increased synthesis of sterol esters while the triacylglycerol content of the cells was unaffected. Sterol esters and triacylglycerols are two classes of yeast lipid located almost exclusively in intracellular low-density vesicles (Cartledge \& Rose, 1973; Clausen et al., 1974). There are two types of vesicle (large and small) present in S. cerevisiae (Cartledge et al., 1977). Sentandreu \& Northcote (1969) have shown that the large vesicle (or vacuole) undergoes fission during the cell cycle and that the progeny of this fragmentation (small vesicles or sphaerosomes) become concentrated at the neck of the bud, suggesting that they are involved in envelope growth. The decreased content of sterol esters and triacylglycerols in phosphate-limited $S$. cerevisiae implies that there is a diminished population of one or both types of vesicle in these cells. If small vesicles are indeed involved in cell-envelope biogenesis, this could explain the changes in wall composition, notably in glucan content, caused by phosphate limitation of growth. It would be interesting to know whether either type of vesicle contains a relatively high proportion of phosphatidylserine since the content of this particular phospholipid was substantially decreased in phosphate-limited yeast.

The changes observed in the levels of phosphorus-containing components in walls and lipids of $S$. cerevisiae subjected to phosphate limitation would not appear to account for the appreciable decrease in the total phosphorus content of these cells. It is likely that this can be attributed in part to a decreased synthesis of polyphosphate, a compound known to be accumulated by $S$. cerevisiae (Dawes $\&$ Senior, 1973). The exact role of polyphosphate in yeast remains to be established although it is presumed to provide a reserve of phosphorus and/or energy. In the light of the present work it may be of some significance that polyphosphate appears to be located in the large vesicle or vacuole (Urech et al., 1978).

We are greatly indebted to Professor A. H. Rose (University of Bath) for the loan of a chemostat and for his interest in this work. A.M.R. thanks the University of Glasgow for a Faculty of Science Research Studentship.

\section{REFERENCES}

BAILEY, R. W. (1969). Methods for the detection of biochemical compounds on paper and thin layer chromatograms: carbohydrates. In Data for Biochemical Research, 2nd edn, pp. 542. Edited by R.M.C.Dawson, D.C.Elliot, W.H. Elliot \& K. M. Jones. Oxford: Clarendon Press.

Cartledge, T. G. \& Rose, A. H. (1973). Properties of low density vesicles from Saccharomyces cerevisiae. In Proceedings of the 3rd International Specialised Symposium on Yeasts, Helsinki, part 1I, pp. 251-259. Edited by H. Suomalainen \& C. Waller. Helsinki: Print Oy.

Cartledge, T. G., Rose, A. H., Belk, D. M. \& GOODALL, A. A. (1977). Isolation and properties of two classes of low-density vesicles from Sccaharomyces cerevisiae. Journal of Bacteriology 132, 426-433.

Clausen, M. K., Christiansen, K., Jensen, P. K. \& BEHNKE, O. (1974). Isolation of lipid particles from baker's yeast. FEBS Letters 43, 176-179.

Dawes, E. A. \& Senior, P. J. (1973). The role and regulation of energy reserve polymers in microorganisms. Advances in Microbial Physiology 10, $135-266$.
Dubois, M., Gilles, K. A., Hamilton, J. K., Rebers, P. A. \& Smith, F. (1956). Colorimetric method for the determination of sugars and related substances. Analytical Chemistry 28, 350-356.

Ellwood, D. C. \& Tempest, D. W. (1972). Effects of environment on bacterial wall content and composition. Advances in Microbial Physiology 7, 83-117.

GAWEHN, K. (1974). D-Mannose and D-mannose-6phosphate. In Methods of Enzymatic Analysis, vol. 3, pp. 1263-1270. Edited by H. U. Bergmeyer. New York and London: Academic Press.

Hossack, J. A. \& Rose, A. H. (1976). Fragility of plasma membranes in Saccharomyces cerevisiae enriched with different sterols. Journal of Bacteriology 127, 67-75.

Hunter, K. \& Rose, A. H. (1972). Lipid composition of Saccharomyces cerevisiae as influenced by growth temperature. Biochimica et biophysica acta 260, 639-653.

JATZKewitz, H. \& MeHL, E. (1960). Thin layer chromatography of brain lipids: hydrolytic and breakdown products. Zeitschrift für physiologische Chemie 320, 251-257. 
Johnson, B., Brown, C. M. \& Minnikin, D. E. (1973). The effect of phosphorus limitation upon the lipids of Saccharomyces cerevisiae and Candida utilis grown in continuous culture. Journal of General Microbiology 75, x.

Kennedy, E. P. \& Barker, H. A. (1951). Paper chromatography of volatile acids. Analytical Chemistry 23, 1033-1034.

LetTERs, R. (1964). The application of two-dimensional paper chromatographic technique to analysis of phospholipids. Biochemical Journal 93, 313-316.

Lowry, O. H., Rosebrough, N. J., FARR, A. L. \& Randall, R. J. (1951). Protein measurement with the Folin phenol reagent. Journal of Biological Chemistry 193, 265-275.

McMurrough, I. \& Rose, A. H. (1967). Effect of growth rate and substrate limitation on the composition and structure of the cell wall of Saccharomyces cerevisiae. Biochemical Journal 105, 189-203.

Minnikin, D. E., Abdolrahimzadeh, H. \& BaDDILEY, J. (1974). Replacement of acidic phospholipids by acidic glycolipids in Pseudomonas diminuta. Nature, London 249, 268-269.

OWen, P. \& Salton, M. R. J. (1975). A succinylated mannan in the membrane system of Micrococcus lysodeikticus. Biochemical and Biophysical Research Communications 63, 875-880.
Páskoví, J. \& Munk, V. (1960). A combined detecting reagent for the identification of organic acids on paper chromatograms. Journal of Chromatography 4, 241-243.

Phaff, H. J. (1971). Structure and biosynthesis of the yeast cell envelope. In The Yeasts, vol. 2, pp. 135-210. Edited by A. H. Rose \& J.S. Harrison. London and New York: Academic Press.

Rondle, C. J. M. \& Morgan, W. T. J. (1955). The determination of glucosamine and galactosamine. Biochemical Journal 61, 586-589.

Rose, A. H. \& Nickerson, W. J. (1956). Secretion of nicotinic acid by biotin-dependent yeasts. Journal of Bacteriology 72, 324-328.

San Blas, G. \& Cunningham, W. L. (1974). Structure of cell wall and exocellular mannans from the yeast Hansenula holstii. II. Mannans produced in phosphate-limited medium. Biochimica et biophysica acta 354, 247-253.

Sentandreu, R. \& Northcote, D. H. (1969). The formation of buds in yeast. Journal of General Microbiology 55, 393-398.

Trevelyan, W. E., Procter, D. P. \& Harrison, J. S. (1950). Detection of sugars on paper chromatograms. Nature, London 166, $444-445$.

URECH, K., DÜrR, M., Boller, Th., Wiemken, A. \& SchwencKe, J. (1978). Localization of polyphosphate in vacuoles of Saccharomyces cerevisiae. Archives of Microbiology 116, 275-278. 